\title{
DETERMINATION OF BOOK LOAN ASSOCIATION PATTERN USING APRIORI ALGORITHM IN PUBLIC LIBRARIES
}

\author{
Eni Irfiani \\ Sistem Informasi \\ Universitas Bina Sarana Informatika \\ www;//bsi.ac.id \\ eni.enf@bsi.ac.id \\ (*) Corresponding Author
}

\begin{abstract}
One way to increase knowledge is by reading literature from books. The young generation as the nation's hope generation is expected to have a high interest in reading to broaden their horizons. Libraries as a place for literature books to provide various types of books. The use of books available in the public libraries of Depok city is still insufficient as seen from the low number of books borrowed by members, especially among the younger generation aged 17 to 25 years. Therefore it is necessary to have a pattern to see the books that are often borrowed by members so that the supply of the types of books that are most attractive to the younger generation that is provided becomes more varied. The method used to determine the association pattern of lending books to the library is using a priori algorithm. From the research results, there are seven rule associations with books that have the highest confidence value and are most often borrowed simultaneously, namely history books and novels as well as history and philosophy. Based on rule association, it is able to assist library officers in providing the most popular types of books among adolescents. In addition, the research results can be used as a reference in placing the book layout on the shelf based on the books that are most often borrowed simultaneously.
\end{abstract}

Keywords: Apriori Algorithm; Libararies; Pattern Determination Borrowing; Teenager

Abstrak - Salah satu cara menambah pengetahuan dengan membaca literatur dari buku-buku. Generasi muda sebagai generasi harapan bangsa di harapkan memiliki minat baca yang tinggi untuk memperluas wawasan. Perpustakaan sebagai tempat tersedianya buku-buku literatur menyediakan berbagai ragam jenis buku. Pemanfaatan buku-buku yang tersedia pada perpustakaan umum kota Depok masih kurang dilihat dari jumlah peminjaman buku oleh anggota masih rendah terutama bagi kalangan generasi muda yang berusia 17 sampai 25 tahun. Oleh karena itu perlu adanya suatu pola untuk melihat bukubuku yang sering dipinjam oleh anggota sehingga persediaan jenis buku yang paling diminati generasi muda yang disediakan menjadi lebih bervariasi. Metode yang digunakan untuk menentukan pola asosiasi peminjaman buku pada perpustakaan menggunakan algoritma apriori. Dari hasil penelitian didapatkan tujuh rule association dengan buku yang memiliki nilai confidence tertinggi serta paling sering dipinjam secara bersamaan yaitu buku History book dan novel serta History book dan philosophy. Berdasarkan rule association mampu membantu petugas perpustakaan dalam penyediaan jenis buku yang paling diminati dikalangan remaja. selain itu hasil penelitian dapat menjadi rujukan dalam penempatan tata letak buku pada rak berdasarkan buku yang paling sering dipinjam secara bersamaan.

Kata Kunci: Algoritma Apriori; Penentuan Pola; Peminjaman; Perpustakaan; Remaja

\section{INTRODUCTION}

Libraries are places and providers of formal and non-formal learning facilities. However, the use of public libraries for the community is not optimal. The population of Depok city who are teenagers is 257,320 (BPS Kota Depok, 2018) and the number of teenagers who borrow books from the Depok city public library is around 120 borrowings in a period of three months. Based on these data, it shows that teenagers still lack interest in borrowing books from the Depok city library. One way to foster reading interest among adolescents is to determine the pattern of borrowing books that are often borrowed based on simultaneous borrowing so that they can become a reference in the provision of new books to the library. The resulting association rules are also useful in making it easier to locate books based on the types of books that occur most frequently together.

The books available in the public library in Depok have many variations, but the use of loan transaction data does not yet exist for library 
purposes (Rico \& Gultom, 2017). The absence of a pattern for classifying books based on borrowing data has resulted in officers experiencing difficulties when searching for books (Anas, 2014). The placement of books on the shelf has not yet been arranged based on the similarity of borrowing books (G. Mandias, Rotikan, Mende, \& Toar, 2017). so that the problem can be needed data mining methods to extract large amounts of data (Yanto \& Kesuma, 2017). The technique used to determine the characteristic pattern of book lending that most often appears together is the apriori algorithm (Srikanti, Yansi, Norhavia, Permana, \& Salisah, 2018). The following is the research literature that will be used, among others:

Table 1. Research Literature

\begin{tabular}{|c|c|c|}
\hline Research & blem (RP1) & Literatur Supports \\
\hline \multirow{4}{*}{ RP1 } & \multirow{4}{*}{$\begin{array}{l}\text { Searching for books on bookshelves } \\
\text { takes a long time due to the } \\
\text { irregular layout of the books }\end{array}$} & $\begin{array}{l}\text { Officers have difficulty placing books that are often borrowed by library } \\
\text { members because the books available on the bookshelf are very large. (G. F. } \\
\text { Mandias, Sandag, Takalumbide, \& Wahongan, 2018) }\end{array}$ \\
\hline & & $\begin{array}{l}\text { The books on the bookshelf are not well organized in the library (Yanto \& } \\
\text { Kesuma, 2017) }\end{array}$ \\
\hline & & $\begin{array}{l}\text { Officers have difficulty finding books on the bookshelves in the faculty library } \\
\text { (Srikanti et al., 2018) }\end{array}$ \\
\hline & & $\begin{array}{l}\text { Officers have difficulty in searching for books with a large number of books } \\
\text { (Saefudin \& Fernando, 2020) }\end{array}$ \\
\hline \multirow{3}{*}{ RP2 } & \multirow{3}{*}{$\begin{array}{l}\text { There is no grouping of books } \\
\text { borrowed by library members and } \\
\text { the pattern of borrowing books that } \\
\text { are often borrowed by library } \\
\text { members }\end{array}$} & $\begin{array}{l}\text { There is no data processing for borrowing books into an association pattern } \\
\text { based on lending data (Anas, 2014) }\end{array}$ \\
\hline & & $\begin{array}{l}\text { There is no linkage pattern between books borrowed by library members } \\
\text { (Santoso, 2017) }\end{array}$ \\
\hline & & $\begin{array}{l}\text { There is no pattern of relationship between students and school grades } \\
\text { (Grand, 2018) }\end{array}$ \\
\hline \multirow{6}{*}{ RP3 } & \multirow{6}{*}{$\begin{array}{l}\text { there is no use of big data in lending } \\
\text { books in the library }\end{array}$} & $\begin{array}{l}\text { There is no data exploration and use of big data in libraries to determine the } \\
\text { correlation and association of data that often arise ((Sahoo \& Mishra, 2015) }\end{array}$ \\
\hline & & $\begin{array}{l}\text { lack of use of big data on book lending transactions on campus (Rico \& } \\
\text { Gultom, 2017) }\end{array}$ \\
\hline & & $\begin{array}{l}\text { There is no use of big data from the information system for borrowing books } \\
\text { to form a pattern for borrowing books by library members (Subianto, Ar, \& P, } \\
2018 \text { ) }\end{array}$ \\
\hline & & $\begin{array}{l}\text { library operational activities produce big data but there is no use of this big } \\
\text { data for library progress (Anas, 2016) }\end{array}$ \\
\hline & & $\begin{array}{l}\text { There is no use of big data in library databases for library purposes } \\
\text { (Prabowo \& Ramdani, 2020) }\end{array}$ \\
\hline & & $\begin{array}{l}\text { There is no use of big data in the lending transaction database as a } \\
\text { recommendation for user characteristics (Nugraha, Muhajir, \& Febrian, } \\
\text { 2019) }\end{array}$ \\
\hline
\end{tabular}

From the results of the research literature in table 1, it is explained that currently, the problems in the library include the absence of the use of big data for borrowing books at the library. This data is useful for determining the rules of the book lending association that often appear at the same time. it is explained that currently, the problems in the library include the absence of the use of big data for borrowing books at the library. based on previous research to solve these problems using several techniques in determining the pattern of association. The results of the study indicate that using apriori algorithm is the best technique for determining the association pattern. gap analysis in previous studies explained that the use of a priori algorithm is only used to determine the association pattern of book lending by all ages.

The purpose of this study is to determine the pattern of book lending association among adolescents using apriori algorithm. the results of the research can be useful for officers in determining the types of books to be provided in the library. The books that become references are books that are often borrowed simultaneously by teenagers to attract reading interest for the younger generation. The arrangement of the layout of the books on the bookshelves in the library can be arranged based on an association pattern.

This arrangement is useful for helping officers to arrange books based on books that are often borrowed simultaneously so that book searches are faster.

\section{MATERIALS AND METHODS}

In this study, the technique used in big data is data mining with the association method with apriori algorithm. The following is a flowchart of the research design carried out, among others: 


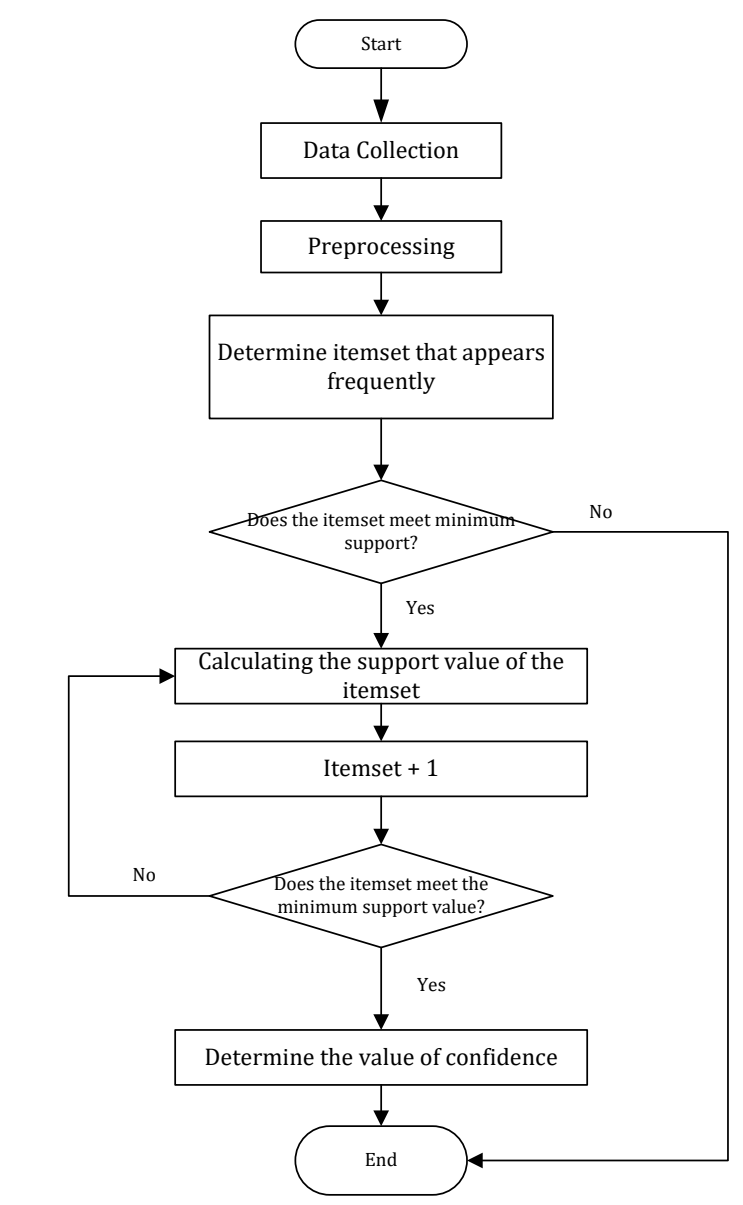

Source: (Irfiani, 2020)

Picture 1. Research Design

In picture 1 , the flowchart of the research design will be carried out by the researcher during the research. The research began with collecting data from book lending transactions at the public library in Depok. This research was conducted from January to March 2019 with a total population of 219 data where book borrowers were teenagers aged 17 to 25 years. The next stage is preprocessing, at this stage, the values contained in the dataset are converted to numeric so that the values in the dataset can be used according to calculations using apriori algorithm formulas. In determining the pattern of book lending association for three months, there are ten types of books available in the public library of Depok, including novels, religion, history, geography, social sciences, arts, sports, philosophy, psychology, applied science. Of the many types of books, the next stage will be to select books that are often borrowed simultaneously by teenagers.

The dataset that has passed the preprocessing stage, the dataset will be processed using apriori algorithm formula, the results of these calculations will get an association rule pattern. The first step in the a priori algorithm is to determine the support value of each book, then the 1-itemset support value is calculated based on the most frequently borrowed books then a selection is made based on the minimum support value of $20 \%$. If the minimum value of support is in accordance with the requirements for the minimum value of support, it will be continued in the next iteration, while if the minimum value of support does not match the requirements, the calculation process will be stopped. To get the support value, a calculation is done using the following formula (Han \& Kamber, 2006):

$\operatorname{Support}(A, B)=P(A \cup B)$

In the second iteration, which consists of 2itemset and the respective support values are recalculated and the fulfillment of the minimum support values is seen. The 3rd iteration is carried out on the 3-itemset by calculating the support value if it matches the minimum support requirements, it will be continued in the next iteration. If the support value does not match the minimum support value limit, the loop is ended then continued by calculating the overall confidence value of the itemset using the formula:

Confidence $(A \rightarrow B)=P(B \mid A) \ldots . .$.
Confidence $(A \rightarrow B)=\frac{\operatorname{support}(A \cup B)}{\operatorname{support}(A)}$

Furthermore, the highest confidence value is determined to produce a rule for pattern association using the formula:

Confidence $(A \rightarrow B)=\frac{\text { support_count }(A \cup B)}{\text { support_count }(A)}$

The final result of the support value and the confidence value that has the highest value will be used as a rule for the book lending association pattern.

\section{RESULTS AND DISCUSSION}

The data collected from book lending transactions at the public library in Depok are shown in table 1 as follows:

Table 2. Book Loan Data

\begin{tabular}{ccccc}
$\begin{array}{c}\text { Member's } \\
\text { Name }\end{array}$ & Gender & Age Group & $\begin{array}{c}\text { Borrow } \\
\text { Date }\end{array}$ & $\begin{array}{c}\text { Kind of } \\
\text { book }\end{array}$ \\
\hline \multirow{3}{*}{ Vina } & Female & $\begin{array}{c}\text { Adolescence } \\
(17-25\end{array}$ & $\begin{array}{c}2019- \\
03-0\end{array}$ & \\
& & years $)$ & $00: 00: 00$ & Novel book \\
& & Adolescence & $2019-$ & \\
Wawan & Male & $(17-25$ & $03-0$ & Philosophy \\
& & years) & 6 & book \\
& & & $00: 00: 00$ & \\
\hline
\end{tabular}




\begin{tabular}{|c|c|c|c|c|}
\hline $\begin{array}{l}\text { Member's } \\
\text { Name }\end{array}$ & Gender & Age Group & $\begin{array}{c}\text { Borrow } \\
\text { Date }\end{array}$ & $\begin{array}{c}\text { Kind of } \\
\text { book }\end{array}$ \\
\hline Dian & Female & $\begin{array}{c}\text { Adolescence } \\
(17-25 \\
\text { years) }\end{array}$ & $\begin{array}{c}2019- \\
03-0 \\
3 \\
00: 00: 00\end{array}$ & $\begin{array}{l}\text { Religious } \\
\text { books }\end{array}$ \\
\hline Raia & Female & $\begin{array}{c}\text { Adolescence } \\
\text { (17-25 } \\
\text { years) }\end{array}$ & $\begin{array}{c}\text { 2019- } \\
03-0 \\
1 \\
00: 00: 00\end{array}$ & $\begin{array}{l}\text { History } \\
\text { book }\end{array}$ \\
\hline Berliana & Female & $\begin{array}{c}\text { Adolescence } \\
(17-25 \\
\text { years })\end{array}$ & $\begin{array}{c}2019- \\
03-1 \\
9 \\
00: 00: 00 \\
\end{array}$ & Novel book \\
\hline Shania & Female & $\begin{array}{c}\text { Adolescence } \\
(17-25 \\
\text { years })\end{array}$ & $\begin{array}{c}2019- \\
02-2 \\
5 \\
00: 00: 00\end{array}$ & $\begin{array}{c}\text { Psychology } \\
\text { book }\end{array}$ \\
\hline Romanisa & Female & $\begin{array}{c}\text { Adolescence } \\
(17-25 \\
\text { years) }\end{array}$ & $\begin{array}{c}2019- \\
03-1 \\
6 \\
00: 00: 00\end{array}$ & Novel book \\
\hline Alifah & Female & $\begin{array}{c}\text { Adolescence } \\
(17-25 \\
\text { years) }\end{array}$ & $\begin{array}{c}2019- \\
02-0 \\
9 \\
00: 00: 00\end{array}$ & $\begin{array}{c}\text { Religious } \\
\text { book }\end{array}$ \\
\hline
\end{tabular}

Source: (Library, 2019)

The data contained in table 2 is part of the sample from the book lending transaction data at the Depok city public library. Book lending transaction data will be converted into preprocessing data where the data will be adjusted to a numeric notation so that the following data is obtained:

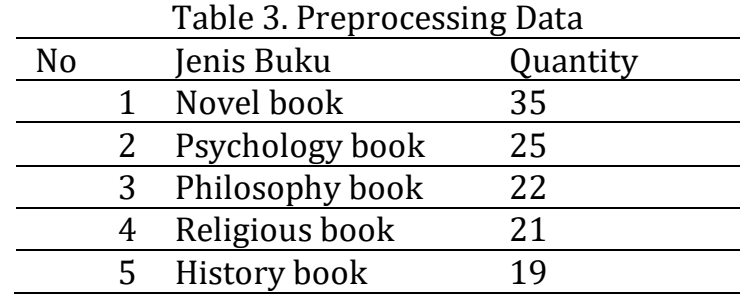

Source: (Irfiani, 2020)

The data in table 3 contains data on the types of books most frequently borrowed by library members, including novels, psychology books, philosophy, religious books, history books. Before calculating using the apriori algorithm, the value of the quantity of each type of book is determined. The results of calculating the value of support on frequent 1-itemsets data are as shown in the following table:

Table 4. Frequent 1-itemsets

\begin{tabular}{clcc}
\hline No & itemset & quantity & support \\
\hline 1 & Novel & 35 & $57 \%$ \\
\hline 2 & Psychology book & 25 & $41 \%$ \\
\hline 3 & Philosophy & 22 & $36 \%$ \\
\hline 4 & Religious book & 21 & $34 \%$ \\
\hline 5 & History book & 19 & $31 \%$ \\
\hline
\end{tabular}

Source: (Irfiani, 2020)
Table 4 contains the itemset that appears most often, namely novels, psychology books, philosophy, religious books, history books. Next, determine the support value for each itemset. The overall result of the minimum support is determined by the support value that has the highest value and according to the minimum support value requirements.

In the next iteration, determine the combination with 2-itemsets then recalculated using the formula for the support value of the 2itemset which often appears simultaneously, as shown in table 5 below:

Table 5. Frequent 2-itemsets

\begin{tabular}{clcc}
\hline No & itemset & qty & support \\
\hline 1 & Novel book, Psychology book & 21 & $34 \%$ \\
\hline 2 & Novel book, History book & 18 & $30 \%$ \\
\hline 3 & Philosophy, History book & 18 & $30 \%$ \\
\hline 4 & Novel book, Religious book & 12 & $20 \%$ \\
\hline Source:(Irfiani, 2020) & &
\end{tabular}

Based on table 5, the entire combination of 2 -itemset that has a support value of $20 \%$ or more is displayed. The next iteration step calculates the support value for 3 -itemsets. The following table is the calculation result with 3 -itemsets:

Table 6. Frequent 2-itemsets

\begin{tabular}{clcc}
\hline No & itemset & qty & support \\
\hline 1 & $\begin{array}{l}\text { Novel book, Psychology } \\
\text { book, Philosophy book }\end{array}$ & 12 & $20 \%$ \\
\hline 2 & $\begin{array}{l}\text { Novel book, Psychology } \\
\text { book, History book }\end{array}$ & 7 & $11 \%$ \\
\hline $3 \quad \begin{array}{l}\text { Novel book, Psychology } \\
\text { book, Religious book }\end{array}$ & 5 & $8 \%$ \\
\hline Source: (Irfiani, 2020) & &
\end{tabular}

Based on the contents of table 6 , it is shown from the 3-itemsets data that there is only one pattern of 3-itemsets that fits the requirements, namely the novel book, Psychology book, philosophy book. In the next step, calculate the confidence value based on 2-itemsets data and 3 -itemsets data that match the minimum support value requirements so that the confidence value results are shown in Table 7 as follows:

Table 7. Rule Association

\begin{tabular}{clcc} 
No & Rule & Support & confidence \\
\hline 1 & $\begin{array}{l}\text { If you borrow a novel, } \\
\text { you will borrow a book of } \\
\text { Psychology }\end{array}$ & $34 \%$ & $60 \%$ \\
\hline & $\begin{array}{l}\text { if you borrow a book of } \\
\text { Psychology then you can } \\
\text { borrow a novel }\end{array}$ & $34 \%$ & $84 \%$ \\
\hline
\end{tabular}




\begin{tabular}{clcc}
\hline No & Rule & Support & confidence \\
\hline 3 & $\begin{array}{l}\text { If you borrow a novel, } \\
\text { you will borrow a History } \\
\text { book }\end{array}$ & $31 \%$ & $51 \%$ \\
\hline 4 & $\begin{array}{l}\text { If you borrow a History } \\
\text { book, you will borrow a } \\
\text { novel }\end{array}$ & $31 \%$ & $95 \%$ \\
\hline 5 & $\begin{array}{l}\text { If you borrow philosophy } \\
\text { then you will borrow the } \\
\text { History book }\end{array}$ & $30 \%$ & $82 \%$ \\
\hline 6 & $\begin{array}{l}\text { If you borrow the History } \\
\text { book then you woll } \\
\text { borrow philosophy }\end{array}$ & $30 \%$ \\
\hline 7 & $\begin{array}{l}\text { If you borrow a novel, } \\
\text { then you will borrow a } \\
\text { religious book }\end{array}$ & $20 \%$ \\
\hline 8 & $\begin{array}{l}\text { If you borrow a religious } \\
\text { book, you will borrow a } \\
\text { novel }\end{array}$ & $20 \%$ \\
\hline $9 \begin{array}{l}\text { If you borrow a novel and } \\
\text { a psychology book then } \\
\text { you will borrow } \\
\text { philosophy }\end{array}$ & $57 \%$ \\
\hline Source: (Irfiani, 2020) & $57 \%$ \\
\hline
\end{tabular}

From the results of the rule association in Table 7, there are 9 rule association patterns with details of 8 rule association patterns from 2itemset and 1 rule association pattern from 3 itemset based on book loan data that most often appear together. Based on the research results, the highest confidence value is on 2-itemset with the type of book borrowed, namely History book and novel book. The support value for borrowing history book and novel book was $31 \%$ and the confidence value for borrowing history book and novel book was 95\%. History book and philosophy book has a support value of $30 \%, 95 \%$ confidence value. From the results of the rule association pattern, it is useful for officers when adding to the latest collection of books based on the results of the books that are most often borrowed simultaneously. Officers will be facilitated in placing the arrangement of books on the shelf based on itemsets that are often borrowed simultaneously, namely novels and psychology books, novels and history books, philosophy and history books and novels, psychology, philosophy.

\section{CONCLUSION}

From the research using apriori algorithm in determining borrowing patterns for adolescents, the most popular books are novel books. There are nine rule associations formed with the highest confidence value, namely History book and novel and History book and philosophy as the books most often borrowed simultaneously by teenagers in the public library of Depok city. Based on the results of the rule association, the books most often borrowed by adolescents will be used as a reference for decision making in providing the latest collection of books in the library. with a variety of books that are increasingly influencing the increasing interest in reading among adolescents. The results of the association rule can be used as a reference in determining the layout of books on bookshelves, making it easier for officers to search for books.

\section{REFERENCE}

Anas, A. (2014). Analisa Pola Peminjaman Buku Perpustakaan Menggunakan Algoritma Apriori. Jurnal Edik Informatika, 1(1), 52-62.

Anas, A. (2016). Analisa Algorithma Apriori Untuk Mendapatkan Pola Peminjaman Buku Perpustakaan Smpn 3 Batanghari. Jurnal Ilmiah Media SISFO, 10(2), 628-641.

BPS Kota Depok. (2018). Jumlah Penduduk menurut Kelompok Umur dan Jenis Kelamin di Kota Depok. Retrieved from https://depokkota.bps.go.id/statictable/201 8/08/23/45/jumlah-penduduk-menurutkelompok-umur-dan-jenis-kelamin-di-kotadepok-2000.html

Grand. (2018). Penerapan algoritma apriori untuk menemukan hubungan data murid dengan nilai sekolah. IKRAITH-INFORMATIKA, 2(1), 7-12.

Han, J., \& Kamber, M. (2006). Data Mining: Concepts and Techniques. Soft Computing (Second Edi, Vol. 54). San Francisco: Elsevier. https://doi.org/10.1007/978-3-642-19721-5

Irfiani, E. (2020). Laporan Akhir Penelitian: Penentuan Pola Asosiasi Peminjaman Buku Mengunakan Algoritma Apriori Pada Perpustakaan Umum.

Library, D. C. (2019). Reports on Borrowing and Returning Books.

Mandias, G. F., Sandag, G. A., Takalumbide, A. G., \& Wahongan, C. (2018). Analisa Pola Peminjaman Buku di Pepustakaan Universitas Klabat Menggunakan Algoritma Apriori. In Konferensi Nasional Sistem Informasi 2018 (pp. 630-633). Pangkalpinang: STMIK Atma Luhur.

Mandias, G., Rotikan, R., Mende, P. A., \& Toar, F. (2017). Sistem Pendukung Keputusan Pemilihan Siswa Berprestasi SMK Kristen 
Tomohon Menggunakan Metode Simple Additive Weighting. Konferensi Nasional Sistem \& Informatika, 484-489.

Nugraha, J., Muhajir, M., \& Febrian, R. (2019). Perbandingan Rough Set Dan Algoritma Apriori Untuk Sistem Rekomendasi Perpustakaan. Jurnal UJMC, 4(2), 25-31.

Prabowo, D., \& Ramdani, F. (2020). Penerapan Algoritma Apriori Untuk Rekomendasi Buku Pada Amikom Resource Center. Information System Journal (INFOS), 3(1), 8-12.

Rico, \& Gultom, B. (2017). Penerapan Algoritma Apriori Dalam Pola Peminjaman Buku ( Studi Kasus: Perpustakaan Stikes Prima Jambi ). SCIENTIA JOURNAL, 6(01), 55-61.

Saefudin, \& Fernando, D. (2020). Penerapan Data Mining Rekomendasi Buku Menggunakan Algoritma Apriori. Jurnal Sistem Informasi, $7(1), 50-56$.

Sahoo, B., \& Mishra, B. S. P. (2015). Data Mining Is A Perpetual Concept For Library And Information Science: An Estimated Overview. International Journal of Digital Library
Services, 5(3), 14-21.

Santoso, H. (2017). Data Mining Penyusunan Buku Perpustakaan Daerah Lombok Barat Menggunakan Algoritma Apriori. In Seminar Nasional TIK dan Ilmu Sosial (SocioTech) 2017 (pp. 25-35). Mataram: STMIK Bumigora.

Srikanti, E., Yansi, R. F., Norhavia, Permana, I., \& Salisah, F. N. (2018). Penerapan Algoritma Apriori Untuk Mencari Aturan Asosiasi Pada Data Peminjaman Buku di Perpustakaan. Jurnal Ilmiah Rekayasa Dan Manajemen Sistem Informasi, 4(1), 77-80.

Subianto, M., Ar, F., \& P, M. H. (2018). Pola peminjaman buku di Perpustakaan Universitas Syiah Kuala menggunakan Algoritma Eclat. Berkala Ilmu Perpustakaan Dan Informasi, 14(1), 35-44. https://doi.org/10.22146/bip.32089

Yanto, R., \& Kesuma, H. Di. (2017). Pemanfaatan Data Mining Untuk Penempatan Buku Di Perpustakaan Menggunakan Metode Association. Jatisi, 4(1), 1-10. 